\title{
Mevlânâ Türbesi Kalemişlerinde Ortaya Çıkartılan Resimlerin Eflatun ve İşrakilik Bağlamında Bir Analiz Denemesi*
}

\author{
An Analysıs of Paintings Recently Discovered in the Mevlana Tomb According to the \\ Philosophy of Ishraqi and Plato
}

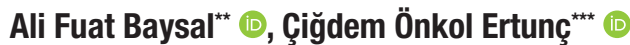

öz

Mevlânâ Celaleddin Rûmî’nin (d. 604/1207 - ö. 672/1273) türbesi günümüze kadar farklı zamanlarda onarımlar geçirmiştir. 2018 yılında başlayan son onarım sürecinde türbenin iç yüzeyini kaplayan kalemişleri üzerinde yapılan raspa çalışmalarında en alt tabakaya ulaşılmaya çalışımıştır. Bu titiz çalışmalar esnasında kubbeyi taşıyan filpâyelerin üst kısımlarında iki tanesi güney ayaklarda, dört tanesi kuzey ayaklarda olmak üzere altı adet devrinin üslubunu gösteren özgün resimler bulunmuştur. Yaklaşık beş yüz yıllık bir geçmişi olan bu resimler, Mevlânâ'nın düşüncesi ile benzerlik gösteren ve İşrakî felsefenin de önder kabul edilen Eflatun düşüncesinin izlerini taşımaktadır. Bilginin aydınlanma yoluyla ve manevi tecrübenin birleşimiyle ortaya çıkması anlamında olan İşrakî felsefe aynı zamanda kişinin ilahi nurla aydınlanarak kemale ermesi manasına gelmektedir. İşrakî anlayışa sahip sanatkâr veya sanatkârlarca tasarlandığını düşündüğümüz resimlerde mistik düşünce sembolleri ustaca kurgulanmıştır. Tasvirlerde kullanılan ağaç figürleri veya mimari yapılarda görülen kandil ve perde gibi eşyalara ait resimler bu kanaatimizi desteklemektedir. Figürlerin yanı sıra resimlerde kullanılan renklerin de psikolojik ve teolojik etkileri saptanarak bu makalede anlatılmak istenen İşrakî felsefe ile bu resimler arasındaki bağlantı kurulmaya çalışılmıştır. Resimlerin üzerinin yıllarca kapalı olmasından dolayı bugüne kadar ilim ve sanat erbabı tarafından herhangi bir yorum, değerlendirme yapılmadığı gibi üzerlerinin ne zaman ve niçin kapatıldığı konusu da meçhuldür. Gün yüzüne çıkartılan bu resimler ilk defa bu çalışmada yorumlanmış, uzun uğraşılarla elde ettiğimiz bilgiler doğrultusunda öncelikle teknik açıdan ardından da Eflatun, Sühreverdî, Mevlânâ denkleminde felsefi açıdan analiz edilmiştir.

\section{Anahtar Kelimeler}

Mevlânâ, Kubbe-i Hadrâ, Kalemişi, Eflatun, Sühreverdî, İşrakî

\section{Abstract}

The tomb of Mawlana Jalal al-Din al-Rumi has undergone several periods of repair until today. During the last repair process that started in 2018 an attempt was made to reach the lowest layer of the tomb where rasping work on the interior design covering the inner surface of the tomb is found. During these meticulous studies, six original paintings representing the style of the period were discovered on the upper parts of the columns carrying the dome, particularly two on the south columns and four on the northern ones. These paintings, which are about five hundred years old,

* 16. Uluslararası Türk Sanatları Kongresi'nde sunulan “Kubbe-i Hadra Kalemişi Tezyinatında Yeni Bulunan Manzara Resimleri" isimli bildiri metnine ilaveler yapılarak genişletilmiş ve makaleye dönüştürülmüştür.

** Sorumlu Yazar: Ali Fuat Baysal (Doç. Dr.) Necmettin Erbakan Üniversitesi, Güzel Sanatlar Fakültesi, Geleneksel Türk Sanatları Bölümü, Konya, Türkiye. E-posta: afbaysal@gmail.com ORCID: 0000-0002-8616-8781

*** Çiğdem Önkol Ertunç (Dr. Öğr. Üyesi), Necmettin Erbakan Üniversitesi, Güzel Sanatlar Fakültesi, Geleneksel Türk Sanatları Bölümü, Konya, Türkiye. E-posta: cigdemertunc@hotmail.com ORCID: 0000-0003-3783-2778

Attf: Baysal, Ali Fuat ve Onkol Ertunc, Cigdem. "Mevlânâ Türbesi Kalemişlerinde Ortaya Çıkartlan Resimlerin Eflatun ve İşrakilik Bağlamında Bir Analiz Denemesi." Art-Sanat, 15(2021): 35-60. https://doi.org/10.26650/artsanat.2021.15.0002 
bear the traces of the illuminationist philosophy's leader, Plato, who had a similar philosophy to Mawlana. Illuminationist (Ishraqi) philosophy, which means the emergence of knowledge through enlightenment and the combination of spiritual experience, also means the maturation of the person by enlightenment with the divine enlightenment. Illuminationist (Ishrâqi) thought symbols were skillfully fictionalized in the paintings, which we think were designed by the artisan(s) of the illuminationist understanding. Tree figures used in depictions or pictures of items such as oil lamps and curtains seen in architectural structures support our opinion. In addition to the figures, the psychological and theological effects of the colors used in the paintings were determined, and an attempt was made to establish a connection between these paintings and the philosophy of Israq, which it is our intention to describe in our study. Since the paintings have been covered for years, no comments or analyses have been made by scientists and artisans until today, and the reasons behind their concealment are unknown. These paintings, which were discovered recently, were evaluated in this study for the first time, and they were first analyzed technically and then philosophically in the context of Plato, Suhrawardi and Mawlana.

Keywords

Mawlana, Qubba-i Hadrâ (Green Dome), Interior Design, Plato, Suhrawardi, Illuminationist

\section{Extended Summary}

After the demise of Mawlana Jalaluddin Rumi in 1273 in Konya, Alameddin Kayser wanted to build a tomb on top of Mawlana's grave. This demand, which was approved by the Palace of the Seljuks, was realized by the Architect Bedreddin from Tabriz, who was one of his followers and known to be an expert in mathematics, chemistry, and alchemy.

There is insufficient information about the shape and characteristics of the tomb, which was completed in 1274. The signature of Abdurrahman from Aleppo is the only source of information imprinted within the ornament inscription on the southern wall of the interior of the tomb, in which there is no document such as foundation record, document, epitaph, signature etc. about the dome. The name of Sultan Bayezid II, the 8th sultan of the Ottoman Empire, is mentioned within the epitaph of this signature. Since the Sultan's reign was between 1481 and 1512, it is understood that the interior design on the surface of the dome was imprinted in the late $15^{\text {th }}$ and early $16^{\text {th }}$ centuries. This period corresponds to approximately 200 years after the construction of the tomb. Considering that the structure has been restored centennially, it is thought that it has been restored twice since it was constructed. More importantly, based on the situation revealed at the last restoration, it is understood that a complete renovation rather than partial configuration was undertaken. Based on the scrapings, it was determined that there were no different styles on the floor, and it was detected that the 15 th century ornament style was original.

Based on these scrapings, 6 paintings $(100 \times 60 \mathrm{~cm})$ imprinted in miniature style were revealed on the sides of the four massive pillars bearing the Kubbe-i Hadra. During the restoration work which started in 2018, it was observed that these miniature paintings, which reflect the style of their time, were covered in the following periods and they were imprinted with interior design . It is unknown why these paint- 
ings, which were revealed on the sides of the massive pillars, were covered over in later periods.

Despite the intensity of patterns within the interior design that was designed with Turkish art styled motives, the mentioned paintings had undetailed, plain, and balanced designs. Among their contents are paintings from nature such as the life of trees and springs as well as depictions of architectural structures. We estimate that these architectural structures depict the Konya Fortress and the Palace of the Seljuks. While it is apparent that each imprinted painting is differentiated from the others with slight differences, we can evaluate these miniature paintings, based on their characteristics, as unique examples of interior design art in tomb architecture. Not only is there no information or visuals in the archives concerning these paintings, but also there were no signatures or dates on the paintings themselves. However, since there is a unity of style on the ornament of the structure, it is easy to date it. It is apparent that the miniature paintings have the same period characteristics and style as the interior design on parts of the Dome such as the vault, the massive pillars, and the wall surfaces.

It is worth mentioning that the patterns, motives, and script characters of the interior design, which have survived until today without much deformation, reflect the ornament style of the Timurid period. Our view is supported by the results of the study, namely that the close similarity between the domes of the structures in the miniatures and the dome styles of the Timurid architecture, and the expert expressions of the symmetrical nature depictions $(204 \times 125 \mathrm{~cm})$ on the edges of the upper windows of the southern walls, bear the characteristics of the Timurid period. Furthermore, the craftsman applying this style, whose similar examples are observed in structures in Bursa and Edirne, is Mawlawi Abdurrahaman, the son of Mehmet from Aleppo. It is known that Abdurrahman was a craftsman who graduated from the Bursa school, which was an ecole in the art of ornament and which trained numerous craftsmen. Based on their signatures on the ornaments of the Yeşil Külliye (lit. the Green Campus) which they contributed to, it can clearly be seen that the craftsmen from Tabriz were also working in the Bursa school, which was an ecole. Since Anatolia and Iran were neighboring countries and since they were involved in various interactions in terms of culture and civilization throughout history, it was highly possible that craftsmen from Tabriz came to Konya and worked on the ornaments of the Mawlana's Tomb or ornaments of similar structures as well. Therefore, the conclusion could be drawn that the Timurid style may very possibly have been used in the ornaments of the Kubbe-i Hadra and that these craftsmen contributed to the implementation of this style.

We can see the traces of Ishraqi philosophy based on the oil lamp motif in the paintings. We can understand from the works of İsmail Rusûhi Ankaravi, an important Mevlevi Grandfather, that there is a close relationship between Mevlevi and Ishraqi. 
Likewise, the fact that one of the architectural structures in the tables resembles the Eflatun Masjid on Alâeddin Hill in Konya, and also the relation between Plato and Ishraqi, has caused our research to move in this direction. It is known that the way of thinking and the philosophical views of Plato, Suhreverdi, and Mevlânâ maintain a close relation to one another. Therefore, it was thought that the paintings in the tomb of a significant thinker such as Mevlânâ Celaleddin-i Rumi had a philosophy and that they were portrayed according to this understanding. When the figures, such as castle, hill, curtain, etc. portrayed in the paintings were analyzed in the context of Ishraqi, our evaluations were concluded in this direction.

The Kubbe-i Hadra interior design, which we consider to have been completed with the skills of these craftsmen from Tabriz, together with its typeset, is the most important example in Konya to incorporate the ornament style of the Timûrid-influenced Sultan Bayezid II. era in regards to pattern, motive, and color. 


\section{Giriș}

Mevlânâ'nın vefatının ardından mezar yeri olarak şehir surları dışında yer alan Selçuklu sarayına ait gül bahçesi seçilmiş ve naaşı buraya defnedilmiştir. Kabrin üzerine Muînüddin Süleyman Pervâne'nin eşi Gürcü Hatun ve Alâmeddin Kayser'in teşebbüsleri ile mimar Tebrizli Bedreddin'e bir türbe yaptırılmıştır' ${ }^{1}$. Kubbe-i Hadrâ olarak bilinen ve 1274 yılında inşası tamamlanan türbenin biçimi ve özelliği hakkında net bir bilgi olmamasına karşın kalemişi tezyinatını, kubbenin iç kısmında yer alan kitabeye göre Sultan 2. Bayezid (1481 -1512) döneminde Halepli Abdurrahman isimli sanatkârın yaptı̆̆ anlaşılmaktadır². Söz konusu kitabe; "Yeşil Kubbe, Mehmet Han'in oğlu, kendisinden yardım talep edilen, Allah tarafindan saltanatı teyit edilen Sultan Bayezid'in hükümdarlı̆̆ zamanında, zaylf kulu, Halepli Mehmet oğlu Mevlevi Abdurrahman eliyle nakşedilmiştir" "şeklindedir. Kitabedeki bilgilerin yanı sıra 2018 yılında başlayan restorasyon sürecinde yapılan raspa çalışmalarında elde edilen bulgulardan Yeşil Kubbe'nin 2. Bayezid devrinde büyük bir onarım geçirdiği ve iç mekân tezyinatında eskiye ait herhangi bir iz bırakılmadan tamamen yenilendiği görülmektedir. Zeminden herhangi bir farklı buluntu çıkmaması önemlidir çünkü ortaya çıkan sonuçtan bugünkü mevcut tezyinatın bu dönemde uygulandığ 1 ve son beş yüz yıllık süre içerisinde döneminin özgün nakışlarının korunduğu, geçmişte yapılan onarımlarda nakışlar üzerinde kısmi yenilemeler olsa da nakışların aslına sadık kalınarak yenilendiği ve önemli bir değişikliğe uğramadan günümüze ulaştığı anlaşılmaktadır. Onarımlar içerisinde en dikkat çeken çalışma Derviş Osman tarafından 1758 yılında yapılan restorasyondur. 2018 onarımı esnasında ortaya çıkan bir imzada yapının 1172/1758 yılında Kayserili Mevlevi Hacı Derviş Osman tarafından yenilendiği görülmektedir. Söz konusu Derviş Osman'ın da özgün kalemişlerine çok fazla müdahale etmeden bir kısım renklerde değişiklik yaptı̆̆ı, kalın tahrir çektiği, fazla miktarda altın kullandığı, desenlerin bir bölümünün üzerlerini boya ile kapattığı anlaşılmaktadır ${ }^{4}$.

Makalemizin konusunu teşkil eden resimlerin üzerleri de muhtemelen bu dönemde kapatılmıştır.

\section{Manzara Resimleri}

2018 yılı onarımında Kubbe-i Hadrâ'yı taşıyan dört filpâyenin üst kısımlarındaki bingi yüzeylerinde yapılan raspa çalışmalarında 100 x $60 \mathrm{~cm}$. ebatlarında 6 adet tablo hâlinde resimler ortaya çıkartılmıştır. Resimlerin muhteviyatında tepe, kale, mimari yapılar, nehir, kapı, perde ve kandil gibi çeşitli unsurlarla birlikte servi, bahar dalı, süsen, hindiba gibi nebati tasvirler yer almaktadır.

1 Ali Fuat Baysal, Kubbe-i Hadrâ Kalemişi Tezyînâtı ve Onarımı (Konya: Palet Yayınları, 2020), 9.

2 Ali Fuat Baysal ve Ayşe Zehra Sayın, "Restorasyon Sonrası Kubbe-i Hadrâ Kalem İşleri Üzerine Değerlendirme", ISTEM Dergisi 33 (2019), 39-64.

3 Baysal, Kubbe-i Hadrâ Kalemişi Tezyînâtı, 13.

4 Baysal, Kubbe-i Hadrâ Kalemişi Tezyînâtı, 10. 


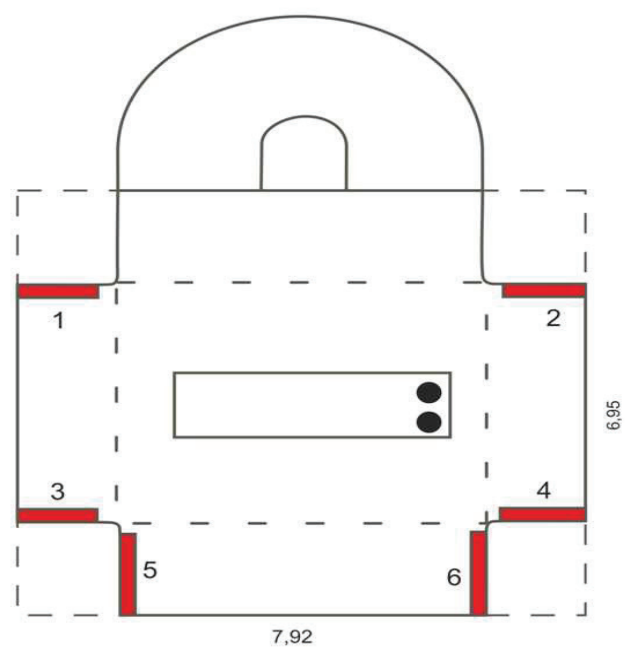

G. 1: Manzara Resimlerinin Bulunduğu Birimler (Çizim: Ali Fuat Baysal)

Söz konusu resimlere ait arşivlerde bilgi veya görsel malzemeler bulunmamasının yanı sıra mevcut resimlerin üzerlerinde herhangi bir imza veya tarihe de rastlanmamıştır. Ancak kompozisyon ve çizgisel ifadeler devrin özelliklerini yansıtmaktadır. Bununla birlikte yapının genel tezyinatında üslûp birliğinin olması sözü edilen resimlerin de aynı dönemin eserleri olduğunu göstermektedir. Yapının genelinde Türk motifleriyle tasarlanmış kalem işlerindeki desen yoğunluğuna karşın çok fazla detaya girmeyen sade ancak anlam yüklü tasarımlara sahip olması dikkat çeker. Resimlerin Mevlânâ gibi bir şahsiyetin türbesinde yer alması, bunların vasıfsız, sıradan resimler olamayacağını, mutlaka felsefi bir düşüncenin, bir tefekkürün ürünü olmasını gerekli kılmaktadır. Zira metodolojisinde insanın sahip olduğu hakikatleri anlatmakta sembolsanat anlayışını tercih eden Mevlevilik kültüründe sembolün önemli bir yeri olduğu bilinmektedir ${ }^{5}$. Resimlerin değerlendirilmesi ve çözümlenmesinde bu noktayı nazar-1 dikkate alarak, teknik ayrıntıların dışında Mevlânâ'nın düşüncesini, düşüncesine etki eden unsurları, dönemin felsefi anlayışını ve birtakım sembolleri incelemenin önemli olduğu kanısındayız.

Bu makale ana hatlarıyla iki kısımdan oluşmaktadır. Birinci kısımda resimlerin türbe içerisinde bulundukları yerleri, ölçüleri ve içerikleri gibi teknik boyut; ikinci kısımda ise resimlerde yer alan sembollerin felsefi anlamları üzerinde durulacaktır. Sonuçta mistik düşüncenin bir ürünü olarak değerlendirdiğimiz bu resimler, özellikleri itibariyle de türbe mimarisi içerisinde görebildiğimiz kalemişi sanatına ait nadide örneklerdir ${ }^{6}$.

5 Murat Özer, Sikkenin Altındaki Sanat, Türk Dünyasında 'Mevlevilik've 'Sanat' Yansımalarl (Eskişehir: Türk Dünyası Vakfı Yayınları, 2013).

6 Semih İrteş, "Mevlânâ Türbesi Kubbe-i Hadra Kalemişi Restorasyonunda Yeni Buluntular", Lale Kültür Sanat ve Medeniyet Dergisi 1 (2020), 19. 


\subsection{Güneydoğu Filpâye Üzerinde Yer Alan 1. Tablo}

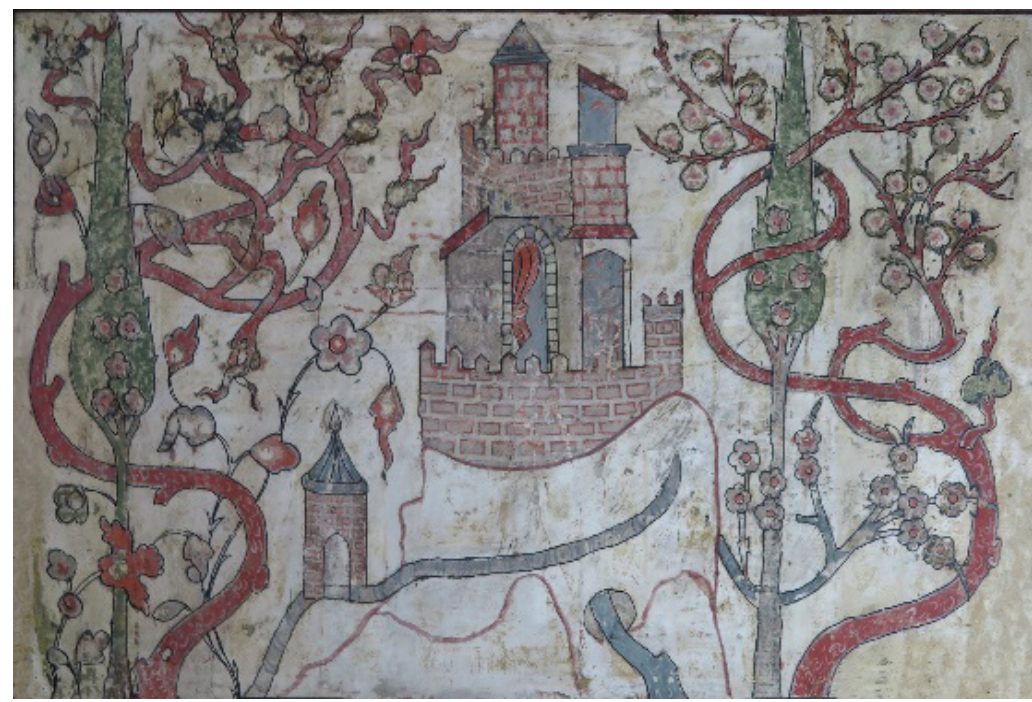

G. 2: Güneydoğu Filpâyede Yer Alan Tablo (Fotoğraf: Ali Fuat Baysal)

Güneydoğu filpâye üzerinde yer alan bu tasvirin merkezinde bir tepe, tepenin üzerinde kuleleri ve burçları bulunan bir kale yapısı, bu kale yapısı içerisinde, girişinde kırmızı perde bulunan bir saray tasviri söz konusudur. Kale yapısının duvarları üzerine gri bej renkli ritmik örüntülü tuğla şekilleri çizilmiş, tuğlaların etrafı kızıl tonlarda gölgelendirilmiştir. Kapıda bulunan perdeye hareket kazandırılmıştır. Yine bu kapının yapıya nispetle daha büyük bir şekilde tasvir edilmiş olmasıyla vurgulanmak istenen yapının önemli bir alan olduğudur. Perde ve kapının nispetinden kalenin bu kısmında bir saray olduğu düşüncesi doğmaktadır. Kaleden aşağıdaki yapıya doğru bir yol gitmektedir. Bu güzergâhta tepenin eteklerinde kemerli ve üzeri piramidal külahla örtülü bir yapı bulunmaktadır (G. 2). Mevcut resimdeki betimlemelerden tepenin Alâeddin tepesini, kalenin Konya iç kalesini, yapının ise Alâeddin Tepesi üzerinde yer alan Selçuklu Sarayını işaret ettiğini düşünmekteyiz. İ.H. Konyalı'nın (d.1896 - ö.1984) "Üst kısmının üzerinin tuğla ile örtüldüğüne dair izler vardır" ifadesinden de anlaş1lacağı üzere Selçuklu Sarayı olarak düşündüğümüz bu yapının üst tarafları kubbe ve eğimli çatı ile kapatılmıştır. Kale yapısının alt tarafında küçük boyutta kale kapısı diyebileceğimiz bir mimari yapı görülmektedir. Ayrıca tepeden aşağıya doğru tünel benzeri dairevi formun içerisinden çıkan şeyin de nehir olması muhtemeldir. Tepenin eteklerinde kemerli ve üzeri piramidal külahla örtülü küçük yapı ise makalenin giriş kısmında bahsedilen Alâeddin Tepesinin biraz uzağındaki gül bahçesinde bulunan ve Mevlânâ'nın defnedildiği Kubbe-i Hadrâ yapısı olmalıdır. Yapı Matrakçı Nasuh'un Konya minyatüründeki türbeyle benzer şekilde tasvir edilmiştir (G. 3).

7 İ. Hakk1 Konyalı, Âbideleri ve Kitabeleriyle Konya Tarihi (Konya: Enes Kitap Saray1, 1997), 182. 


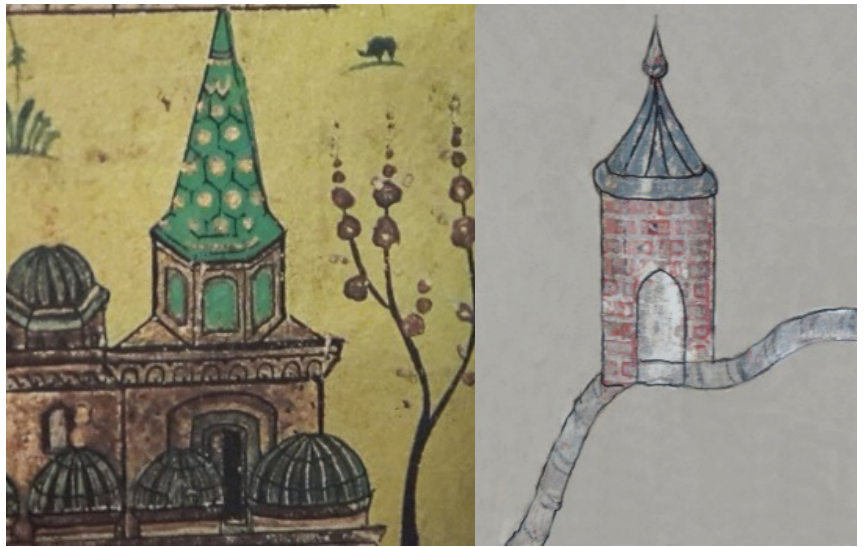

G. 3: Matrakçı Nasuh'un Konya Minyatüründeki Kubbe-i Hadrâ (Fotoğraf: Ali Fuat Baysal)

Mimari yapıların sağ ve sol taraflarında ağaç gruplarından oluşan bitkisel tasvirler yer alır. Her iki tarafta da birer bahar dalı ve birer servi ağacı bulunmaktadır. Bahar dalları âdeta bir sarmaşık gibi resmedilmiştir. Gövde kısmında kırmızı renk kullanılan bahar dalı çiçekleri beyaz renkle, çiçeklerin merkez kısımları yine kırmızı can noktalarının etrafina pembe ile degrade şekilde renklendirilmiştir. Bahar dallarında kullanılan çiçekler bazı noktalarda farklılaşarak hatayi formunda kullanılmıştır. $\mathrm{Bu}$ tarz betimlemeler daha çok sol taraftaki bahar dalı üzerinde bulunmaktadır. Hatayi motifleri dalların uç kısımlarına yerleştirilmiştir.

\subsection{Güneybatı Filpâye Üzerinde Yer Alan 2. Tablo}

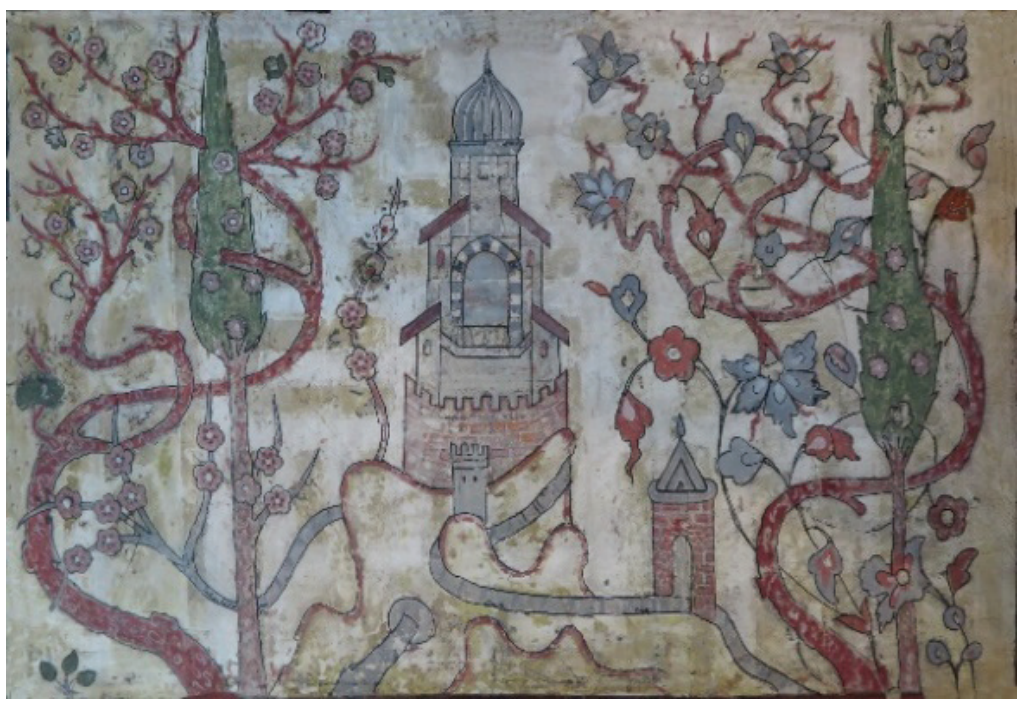

G. 4: Güneybatı Filpâyede Yer Alan Tablo (Fotoğraf: Ali Fuat Baysal) 
Güneybatı filpâyede yer alan resimde yine bir yüksek tepe, bu tepenin üzerinde kuleleri ve burçları bulunan bir kale yapısı, bu kale yapısının iç kısmında geniş kemer açıklığı bulunan mimari yapı ve kalenin alt tarafında küçük boyutta kale kapısı diyebileceğimiz bir yapının tasvirleri bulunmaktadır. Tepenin eteklerinde yine kemerli ve üzeri piramidal külahla örtülü önceki tablodakinin benzeri bir yapı görülmektedir. Ancak 1. tabloda sol tarafta bulunan bu mimari yapı, bu resimde sağ tarafta yer almaktadır. Farklı yönden resmedildiğini düşündüğümüz bu küçük yapı da Kubbe-i Hadrâ olmalıdır (G. 4). Kale içerisindeki saray tasvirinin kemer yapısı bugünkü seyir köşkünün kemeriyle benzerlik göstermekle birlikte, siyah beyaz renklerle düzenlenen bu kemer yapısı oldukça geniş görünmektedir. Burada dikkat çeken husus, kale içerisindeki mimari yapının kubbesinin Timur dönemi mimarisini anımsatan tarzda olmasidir.

Mimari yapıların sağ ve sol taraflarında yine bünyesinde çiçekler bulunan servi ağacı ve bu ağaca sarılmış bahar dalları bulunmaktadır. Ancak bu bahar dalları diğerlerine göre daha karmaşık ve kıvrımlı olup sağ taraftaki dallarda yer alan çiçekler stilize edilmiş hatayi üslubundadır. Bezeme özellikleri olarak güneydoğu filpâye üzerinde bulunan manzara resmi ile aynı özellikleri taşıyan tasvirde diğer nebati gruplardan farklı olarak sol alt tarafta bahar dalının hemen alt kısmında ufak üçlü yaprak gruplamasından oluşmuş bir bitki bulunmaktadır.

\subsection{Kuzeydoğu Filpâyenin Güney Cephe Yüzeyinde Yer Alan 3. Tablo}

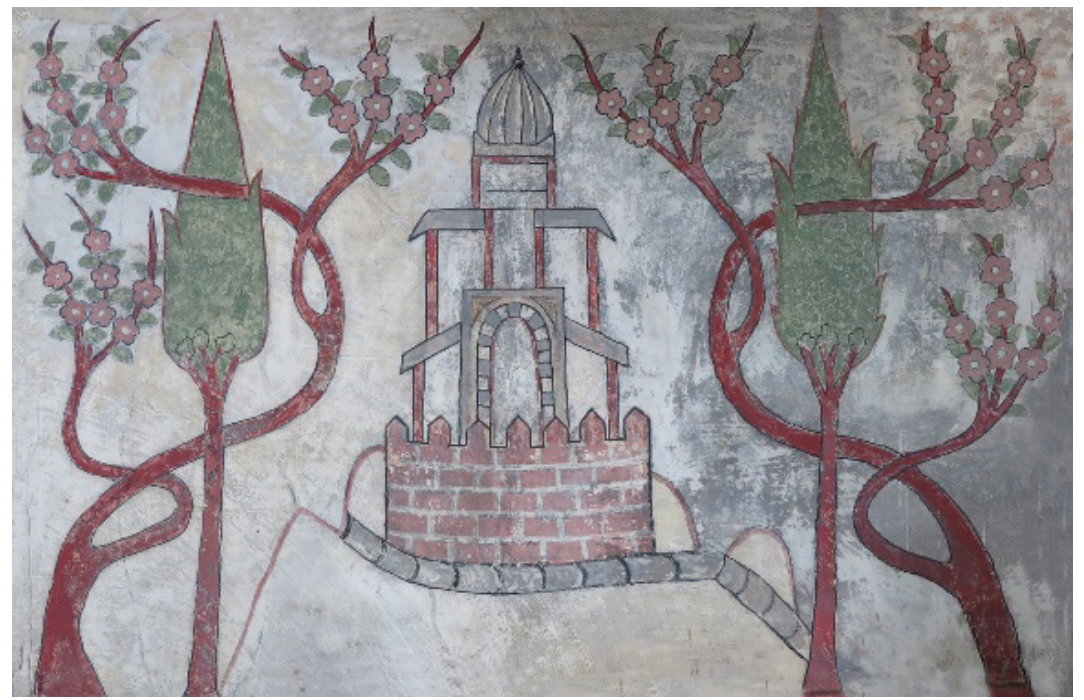

G. 5: Kuzeydoğu Filpâyenin Güney Yüzeyinde Yer Alan Tablo (Fotoğraf: Ali Fuat Baysal)

Kuzeydoğu filpâyenin güneye bakan yüzeyindeki tablo mevcut tablolar içerisinde en sade olanlardan biridir. Bunun nedeni tablonun güney yöne bakması ve insanların 
nazarlarından uzak kalmasından dolayı olmalıdır. Ayrıca bu tabloda daha önceki tablolarda Kubbe-i Hadrâ olarak tanımladığımız yapı tasvir edilmemiş̧ir. Tepe üzerindeki çift katı bu mimari yapının kubbesi de yine Timurî özelliği taşımaktadır.

Tablonun her iki kenarına uygulanan nebati tasvirler de tıpkı mimari yapılar gibi oldukça sade görünümlüdür. Bahar dallarının sarmaladığı servilerde çiçek yoktur (G. 5).

\subsection{Kuzeybatı Filpâyenin Güney Cephe Yüzeyinde Yer Alan 4. Tablo}

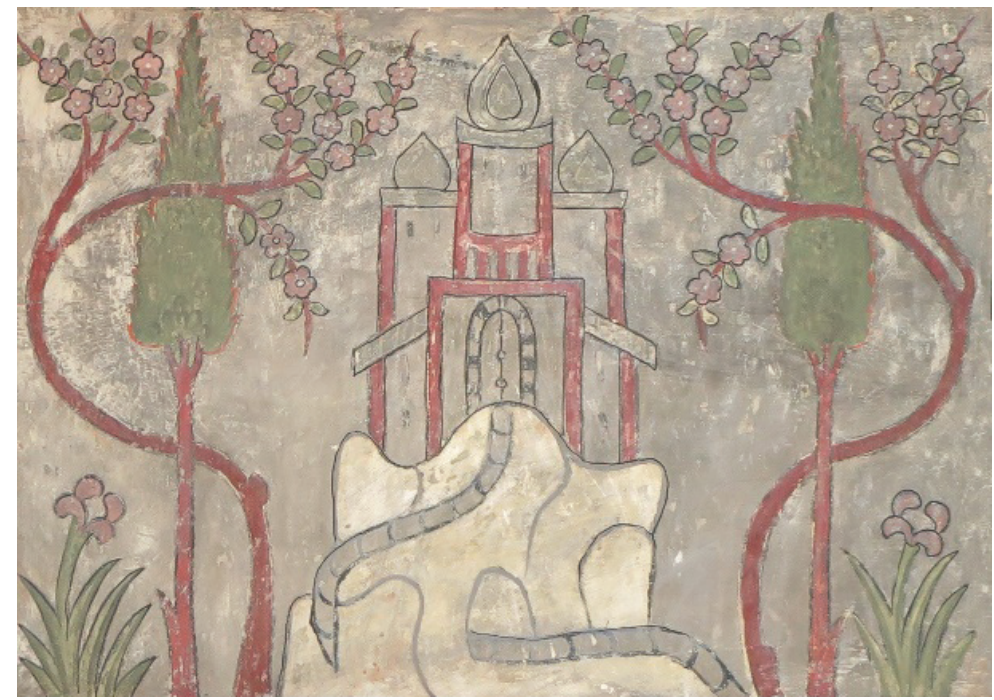

G. 6: Kuzeybatı Filpâyenin Güney Yüzeyinde Yer Alan Tablo (Fotoğraf: Ali Fuat Baysal)

Kuzeybatı filpâyenin güney cephesinde bulunan ve diğerlerine nazaran en sade tasvirlerden biri de bu tablodur. Üç blok hâlinde tasvir edilen bu mimari yapı ve kubbeleri oldukça sade görünümlüdür. Bu tabloda kale yapısı resmedilmemiş, tepenin üzerinde sadece saray tasvir edilmiştir. Kuzeydoğu filpâyedeki gibi alt kısımdaki piramidal külahlı yapı tasviri ve bahar dallarının sarmaladığı servilerde çiçek yoktur. Ancak buraya iri zambak (süsen) çiçekleri çizilmiştir. Renklendirme diğer manzara resimlerine göre daha sade tutulmuştur. Aynı şekilde servilerin de diğer örneklerden farklı olarak daha katmanlı şekilde tasvir edilmesi dikkat çekicidir (G. 6). 


\subsection{Kuzeydoğu Filpâyenin Batı Cephe Yüzeyinde Yer Alan 5. Tablo}

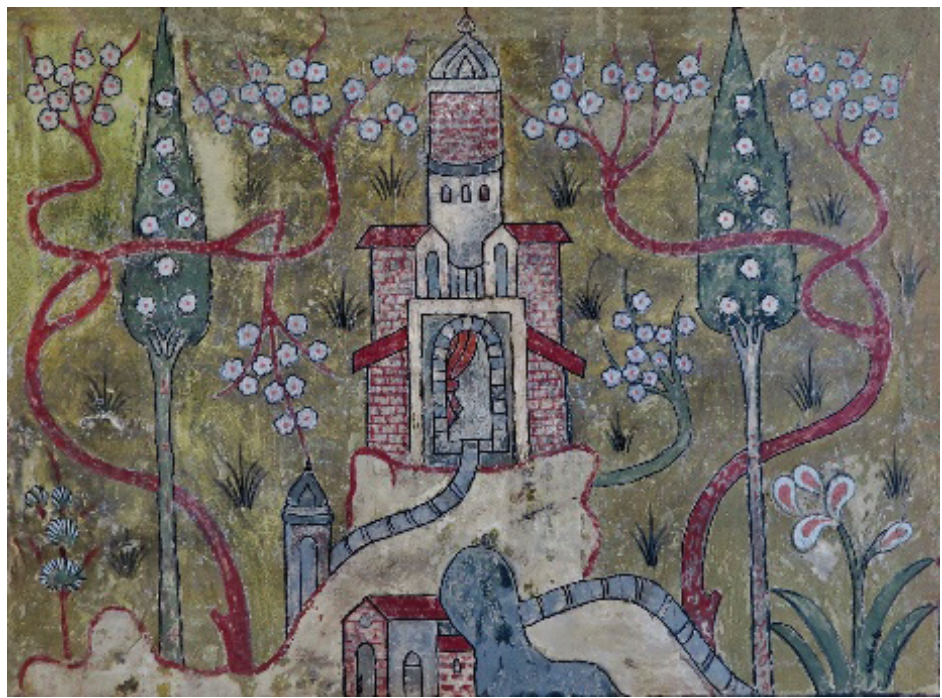

G. 7: Kuzeydoğu Filpâyenin Batı Yüzeyinde Yer Alan Tablo (Fotoğraf: Ali Fuat Baysal)

Kuzeydoğu filpâyenin batı cephesinde bulunan bu tablo, diğerleri içerisinde en yoğun ve en detaylı çizime sahiptir. Zemin renginin yanı sıra, çiçekler, bahar dalları, servi ağaçları kırılan dal görüntüsü ve sivil mimari yapıları ile farklılık arz eder. $\mathrm{Bu}$ ve bundan sonraki resim daha detaylıdır ve işçiliği daha fazladır. Bunun nedeni de muhtemelen insanların görme mesafelerine daha yakın olmasından kaynaklanmaktadir (G. 7).

Diğer resimlerde kale ve içerisinde mimari yapı tasviri olmasına karşın bu resimde bir önceki resimde olduğu gibi kale yapısı yoktur. Bununla birlikte tepenin eteklerinde kırma çatılı sivil mimari örnekleri görülmektedir. Kubbe-i Hadrâ olduğunu düşündügümüz yapı, farklı üslupta resmedilmiş, sol cephede ve arka tarafta yer almaktadır. Tepenin eteğinde görülen yapı iç kalenin kapısı da olabilir. Zira Ebubekir Efendi, Kâtip Çelebi'ye atfen; Konya kalesinin 12 kapısının var olduğunu ve bu kapıların her birinin birer kasr (saray) şeklinde kulelerinin olduğundan bahseder

Tablonun sağ ve sol taraflarında yer alan nebati tasvirleri incelediğimizde yine servi ağaçları ve bahar dallarının bulunduğu görülmektedir. Servilerde çiçekler bulunurken bahar dallarının kıvrımları az, çiçekleri oldukça fazladır. Bunun yanı sıra diğer bahar dallarında gördüğümüz hatayi grubundaki çiçek tasvirleri bu resimde yer almazken var olan çiçekler daha yalın resmedilmiştir. Sol tarafta yer alan bahar dalına dikkatle bakıldığında bir dalının kırık olarak tasvir edildiği görülmektedir. Dikkat çeken bu çizimde doğuşu ve yaşamı simgeleyen bahar dalı ağacının bir dalının kırılması ölümü

8 Konyal, Konya Tarihi, 123. 
yani ahireti niteler şekilde kullanılmış olmalıdır. Bahar dalının alt kısmında gövde kısmı bahar dallarında olduğu gibi kızıl olan çiçek, beyaz ve yeşil tonlarda renklendirilmiş hindiba tasviri bulunmaktadır.

Bu tasvirde de bir önceki tabloda olduğu gibi yine ölümü simgeleyen iri süsen çiçeği yer alırken ot kümeleri yapılar topluluğu ile birlikte kompozisyonu tamamlamaktadır. $\mathrm{Bu}$ tablo ve bundan sonraki diğer tablonun zeminleri sarı ile renklendirilmiştir (G. 7).

\subsection{Kuzeybatı Filpâyenin Doğu Cephe Yüzeyinde Yer Alan 6. Tablo}

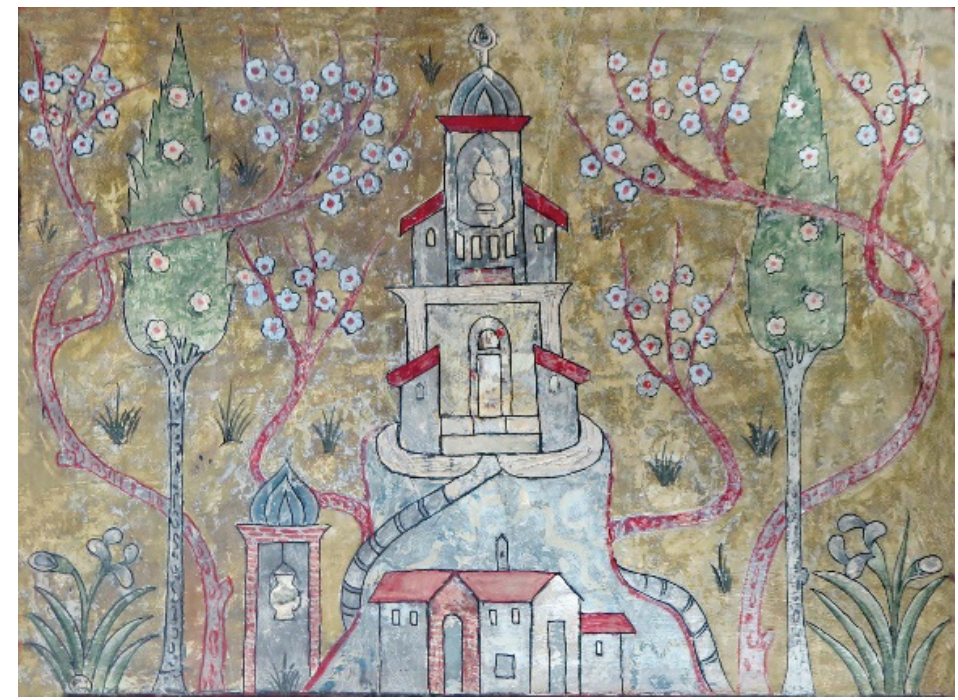

G.8: Kuzeybatı Filpâyenin Doğu Yüzeyinde Yer Alan Tablo (Fotoğraf: Ali Fuat Baysal)

Kuzeybatı filpâyenin doğu cephesindeki bu tablonun yoğunluğu diğerlerine göre fazla ve detaylıdır. Tepe üzerinde tek blok hâlinde kubbeleri Timurî tarzda tasvir edilmiş bir yapının haricinde tepenin eteklerinde de üç blok hâlinde kırma çatılı mimari yapılar göze çarpar. Tepe üzerinde kale olmamakla birlikte tepenin yüzeyi diğerlerine göre düz bir zemin şeklindedir. Kale dışında inşa edildiği görülen bu kubbeli mimari yapı Eflatun Mescidi olmalıdır. Ayrıca bu yapılardaki kandil tasvirleri dikkat çekmektedir. Diğer yapılarda böyle bir remz yoktur.

Tepe üzerindeki mimari yapıların haricinde tepenin alt kısımlarında binalar görülmektedir. Bu binaların bulunduğu mekânın geçmişte Mevlânâ'nın Medresesinin bulunduğu ve bugün Kültürpark olarak isimlendirilen bölge olduğunu söyleyebiliriz. Dolayısıyla resmedilmiş bu yapıların Mevlânâ'nın medresesi olma ihtimali vardır.

Nebati tasvirlerde diğerlerinde olduğu gibi simetrik, çiçeklerle yüklü servi ağaçları, yoğun şekilde tasvir edilmiş bahar dalları bulunmaktadır. Resmin alt kısmında iri çizim zambaklar bulunmaktadır (G. 8). 


\section{Resimlere Felsefi Açıdan Bakış}

Teknik olarak çözümlemeye çalıştığımız bu resimlerin sonuncusunda yer alan kandil tasvirleri dikkat çekici bir motif olarak bizi farklı düşüncelere yönlendirmiştir. Yukarıda bahsettiğimiz gibi kandil resimlerine, Mevlânâ'nın türbesinde sıradan resimlerin uygulanamayacağ kanaatini de eklediğimizde öncelikle Mevlevilik düşüncesi ve onun diğer düşünce sistemleri ile olan bağlantılarından yola çıkarak bir değerlendirme yapabilmemize imkân doğmuştur. Bu yol bizi önce İşrakîlik ekolünün kurucusu Sühreverdî’ye, oradan Eflatun'a ulaştırmıştır.

Ayrıca Mevlânâ'nın düşünceleri, Konya'nın eski resimleri, Mevlânâ ve İslam felsefesi alanındaki uzmanlar ile yaptığımız uzun değerlendirmelerde, resimlerin Mevlânâ (ö. 1273), Eflatun (m.ö. 427-347) ve Sühreverdî (ö. 1191) ekseninde tasavvur edilerek uygulanmış olduğu sonucuna varılmıştır . Esasında Eflatun, Sühreverdî ve Mevlânâ arasında düşünce bağlamında yakın bir ilişkinin varlığı söz konusudur" . "Eflâtun, hakikate varmak ve kâinatın sırlarını çözebilmek için düşüncesini ve duygusunu kendine rehber edinmiş, Mevlânâ ise İslâm 'ı, îmanı ve ilhamı kendine rehber edinmiştir." diyen Şefik Can, aynı şekilde Eflatun ile Mevlânâ'nın düşünce olarak birbirlerine yakın olduğunu, filozof Eflâtun ve mutasavvıf Mevlânâ'nın âlemi var eden varlığın aranması, bulunması, onun anlaşılması ve anlatılması yönünden aynı tarafta yer aldıklarını ifade etmektedir ${ }^{11}$. Eflatun ve Mevlânâ'nın her ikisinde de dinsel ve mistik unsurların dikkat çektiği görülmekle birlikte Mevlânâ'nın Eflatun hakkında oldukça övgü dolu beyitleri Mesnevi de yer almaktadır:

\footnotetext{
"Ey bizim sevdası güzel aşkımız; şadol; ey bütün hastalıklarımızın hekimi; Ey bizim kibir ve azametimizin ilâcl, ey bizim Eflâtun'umuz! Ey bizim Calinus'umuz! 1/24”'12,

"Bir adamın can gözünü, can kulağını Tanrı kapattı mı o adam Eflatun olsa hayvanlaşır! 4/1923”"13,

O zamanin Eflatunu ne derse ona uy. Kendine gel, heva ve hevesi bırak, onun dileğince hareket et. 6/4144"'14.
}

Bu bilgiler ve ilişkiler bağlamında resimleri gözlemlediğimizde, türbenin tezyinatını uygulayan nakkaşın bilgelik ve kâmillik noktasında Mevlânâ ile Eflatun arasında münasebet kurduğu, sembol olarak onun türbesinin resmini bilinçli şekilde tasarladığ 1 ve Kubbe-i Hadrâ içine uygulamış olduğu anlaşılmaktadır.

9 Bilal Kuşpınar ve H. Hüseyin Bircan ile 08.08.2019 tarihinde yapılan görüşme kayıtları.

10 Suzan Yalman, “Platondan Şehname’ye; Selçuklu Dönemi Konya’sında Aziz Ziyaretleri Üzerine Düşünceler", Kutsal Mekanlar ve Kentsel Ağlar, ed. A. H. Uğurlu and S. Yalman (İstanbul: ANAMED, 2019), 119140.

11 Şefik Can, Mevlânâ ve Eflatun (İstanbul: Okul Yayınları, 2004), 20.

12 Mesnevi, ed. Abdülbaki Gölpınarlı, çev. Veled Çelebi İzbudak (İstanbul: Milli Eğitim Bakanlığı Yayınları, 1990), $1 / 2$.

13 Mesnevi, 4/156.

14 Mesnevi, 6/128. 


\section{1. İşrakî Felsefe}

Konuyu Eflatun ile ilişkilendirdiğimizde ve son resim tablosundaki kandilleri de göz önüne aldığımızda karşımıza "nur” kavramını sembolleştiren İşrakî felsefe çıkmaktadır. İşrâk kelimesi sözlükte

"Güneşin doğuşu sırasındaki ışıma, aydınlanma, tan ağarışı" gibi anlamlara gelir. Terim anlamında ise epistemolojik açıdan akıl yürütmeye veya bir bilgi vasıtasına gerek kalmadan bilginin doğrudan içe doğması, iç aydınlanma, keşfve zevke (mânevî tecrübe) dayanan bilgi için kullanılır. Ontolojik açıdan işrak, aklî nurların tecellisi sonucunda varlığın zuhur edip gerçeklik kazanmasıdır. Aynı zamanda işrak, arınan insan nefsinin ilâhî nurların tecellisiyle aydınlanıp kemale ermesi şeklinde ahlâkî anlamda da kullanılmaktadır ${ }^{15}$.

Sühreverdî kurucusu olduğu felsefenin özü niteliğinde olan nur ilmini anlatırken Eflatun'dan bahsetmektedir. "Nur ilmi veya onunla ilgili olan şeylerde Allah yolundan gidenler bana yardım ettiler, bu ilim, kudret ve nur sahibi hikmetin rehberi ve önderi olan Eflatun zevkinin ta kendisidir" ${ }^{16}$.

Kaynaklarda, İşrâki felsefenin kurucusu Sühreverdî el- Maktûl'ün Konya'da bulunduğu, Selçuklu Sultanı 2. Kılıçaslan (1155-1192)'ın onu bir müddet misafir ettiği ve kendisiyle defalarca görüştüğü, veziri Emir Kemaleddin Kamyar ve saray erkânının da kendisinden felsefe tahsil ettiği ifade edilmektedir ${ }^{17}$. Eflatun, Mevlânâ ve Sühreverdî arasındaki münasebeti incelediğimizde, Eflatun'un İşrakîliğin önderi, Şehâbeddin esSühreverdî el-Maktûl'ün İşrakîliğin kurucusu, Mevlânâ'nın ise İşrakîliğin sûfi ekol içerisinde sürdürücüsü olarak tanımlandığını görüyoruz ${ }^{18}$. Mevlânâ ile İşrakîlik arasındaki ortak nokta yine Eflatun olmakla birlikte ${ }^{19}$; yüksek hakikatlere akıl yolundan ziyade ilhamla ulaşılabileceği düşüncesi de Mevlânâ'nın felsefesinin İşrakîlik felsefesi ile benzerliğini ortaya koymaktadır ${ }^{20}$. Aynı hakikatin farklı bir yansıması olan İşrakîlik ve Mevlevilik iç içedir ${ }^{21}$. Diğer yandan Mevlânâ ve İşrakîlik konusunda önemli bir isim İsmail Rusûhî Ankaravî’ dir (ö.1631)22. Mevlevilik tarikatında şeyhlik makamına kadar erişerek önemli bir konum elde eden ve yazmış olduğu Mesnevi

15 Mahmut Kaya, “İşrâkıyye”, Türkiye Diyanet Vakfi İslâm Ansiklopedisi, c. 23 (İstanbul: Türkiye Diyanet Vakfi Yayınları, 2001), 435-438.

16 Adem Çatak, "Sühreverdi'nin Felsefi Tasavvurunda Marifet”, Sühreverdi ve Işsak Felsefesi, ed. M. Nesim Doru, Kamuran Gökdağ ve Yunus Kaplan (Ankara: Otto Yayınları, 2015), 192.

17 Yusuf Ziya Yörükan, Şihabeddin Sühreverdi ve Nur Heykelleri (İstanbul: İnsan Yayınları, 1998), 18-19.

18 Rıfat Okudan, "İşrak Filozofu Sühreverdî Maktûl ve Eserlerindeki Üslup ve Belağat” (Doktora Tezi, Süleyman Demirel Üniversitesi, 2001), 161.

19 Yalman, "Platondan Şehname’ye; Selçuklu Dönemi Konya'sında Aziz Ziyaretleri Üzerine Düşünceler”, 119140.

20 Can, Mevlânâ ve Eflatun, 34.

21 Bilal Kuşpınar, 08.08.2020 tarihli görüşme kayıtları.

22 Bilal Kuşpınar, Isma 'il Ankaravi on the Illuminative Philosophy (Kuala Lumpur: International Institute of Islamic Thought \& Civilization (ISTAC), 1996), 211-213. 
şerhiyle Hazret-i şârih diye meşhur olan Ankaravî, aynı zamanda XVII. yüzyılın ilk yarısında, Sühreverdî'nin Heyâkilü'n-nûr (Nur Heykelleri) adlı eserini de İzâhü'lhikem (Bilgeliğin Aydınlanması) başlığı altında şerh etmiştir. Hem Mevlevi Dedesi hem İşrâkî filozof olan Ankaravî'nin bir dönem Konya'da bulunduğu dikkate alındığında Kubbe-i Hadrâ'da yer alan resimlerin uygulanması ve sembollerin kullanımı daha iyi anlaşılmaktadır ${ }^{23}$.

\section{Resimlerde Bulunan Ortak Semboller}

Resimlerdeki figürlerin evreni, kozmozu, varoluşu ifade ettiği görülürken, kompozisyonlarda iki önemli anlatımın varlığı dikkat çeker. Bunlardan birincisi; tepe, nehir, kale ve mimari yapılar; ikincisi ise ağaç, çiçek ve diğer bitkisel motiflerdir. Birincisinde insan ve onun tekâmülü, ikincisinde insanın varoluşu söz konusudur.

\subsection{Tepe-Kale-Saray}

Tabloların hepsinde tepe tasviri kullanılmıştır. Bu sembolün yücelik ve yükselme anlamlarına geldiğini biliyoruz ${ }^{24}$. İnsan-1 kâmil olma yolunda ilerlemek için belirli yolları aşmanın ve hayatta mesafe kat ederek yükselmenin gerekli olması mistik hayatta önemli bir merhaledir. Tepe üzerinde bazı resimlerde kale yapısı veya mimari yapılar bulunurken bazılarında sadece mimari yapılar görülmektedir. Resimler birbirlerinin devamı niteliğindedir ve dikkat çeken husus tepe üzerinde burçları olan bir kale yapısının bulunmasıdır (G.2, G. 4, G. 5). İşrakîye felsefesindeki anlayışa göre yön, zaman, mekân kavramları bulunmayan resimlerdeki yapılar insanı temsil etmektedir. Çünkü Sühreverdî’ye göre "komutan olan nur, beden kalesindeyken kalenin meşgaleleri karşısında zafer kazanırsa nur âlemine olan sevgisi cisimlere olandan daha fazla olur; kendi nuru ve kâhir nurlara olan muhabbeti artar ve Nurlar Nuru'na yaklaşır²5."

Sühreverdî, felsefesinde insan bedenini kale olarak tanımlamakla birlikte buradaki resimlerde Âdem ve Havva'nın yaratılış hikâyesinden mülhem cennet bahçesinin tasvir edildiğini de söyleyebiliriz. Çünkü Âdem ve Havva kıssasının özü var oluş bilinci olduğu gibi insanın varlık sebebi de yükselmek, kâmil insan olmaktır. Sühreverdî, insanın nuru arzu etmesi ve derece bakımından nurlara doğru yükselmesinden, nefislerin bedenlerinden sıyrılarak maddi âlemin dışında başka bir âleme, misâl âlemine yükselebileceğinden bahsetmektedir ${ }^{26}$. Bu bağlamda önemli olan arınmak ve yükselmek, yükseldikçe de arınmaktır.

23 Bilal Kuşpınar, 08.08.2020 tarihli görüşme kayıtları.

24 Ö. Faruk Harman, "Dağ", Türkiye Diyanet Vakfi İslâm Ansiklopedisi, c.8 (İstanbul: Türkiye Diyanet Vakfı Yayınları, 1993), 400.

25 A. Kamil Cihan, "Sühreverdî ve İşrâkîlik", İslâm Felsefesi Tarih ve Problemler, ed. Cüneyt Kaya (İstanbul: Türkiye Diyanet Vakfi Yayınları, 2018), 397-427.

26 Mehmet Alıc1, "Sühreverdî’nin İşrâk Düşüncesini İnşâda Kadim Etimolojilerin Yeri”, Milel ve Nihal 11/2 (2014), 75 . 
Hakikati anlamak için tasvirlerdeki gibi kaleden dışarıya çıkmak hatta insan için hayatın her anında aşağıdan yukarıya doğru çıkmak zorunluluğu vardır. Çünkü mükemmele ulaşmak için yükselmek gerekir, yükseldiğinde ulaşılan nokta ise hakikatin kendisidir. Yükselmenin bir diğer anlamı miraçtır ki burada Miraç olayına ve miracın varlığına dikkat çekilmektedir. Tabiatıyla bu yorumların temeline sembolik olanın yanında realist olanları da eklemekte fayda olacaktır. Zira Anadolu' da özellikle de Suriye'den Konya'ya bir hat çizilse siyasal hâkimiyetlerin mekânı olan sarayların sun'î tepelere kurulduğunu görürüz. Nitekim bizim de üzerinde durduğumuz tepe bunu gösteriyor. Bu tepeler sadece manevi bir yükselme değil, siyasal bir yükselmeyi de işaret etmektedir ${ }^{27}$. Kale tasvirlerinin bulunmadığı ancak mimari yapılar, tepe ve bahçe tasarımlarının bulunduğu resimler yukarıda bahsettiğimiz şekilde yine insanın yükselişini konu edinmektedir (G.6, G. 7, G. 8).

\subsection{Nehir}

Resimlerde yukarıdan aşağıya doğru inen bir nehir tasviri görülür. Sühreverdî’nin sekizinci iklimin mekânları olarak zikrettiği şehirlerden biri Hurkalya şehridir. Bu şehrin etimolojik ve mitolojik kökenine baktığımızda buranın bir şehirden ziyade bütün zirvelerin üstünde bir mekânı resmettiği görülmektedir. Burası Hara dağının en üst zirvesidir ve ortasındaki nehir aracılığıyla bütün suların arındığı yerdir ${ }^{28}$. Resimlerdeki nehir tasviri bu özelliğe dikkat çekilmiş olmalıdır.

\subsection{Eflatun Mescidi}

Eflatun mescidi olarak bilinen yapı Alâeddin Tepesinde yer almaktadır. Aynı zamanda, Eflâtun Kilisesi, Eflâtun Rasathânesi, Eflatun Saat Kulesi gibi adlarla tanımlanan yapı için İ. H. Konyalı kitabında "makam-ı Eflatun" ifadesini kullanır ${ }^{29}$. Bazı kaynaklar Eflatun'un burada medfun olduğunu rivayet eder ki, bu konuyu ilk ortaya koyan Ebü'l-Hasan Ali b. Ebû Bekir el-Herevî’dir (ö. 611/1214). Herevî, Kitâbü'z-Ziyârât adlı eserinde, "Konya şehrinde büyük caminin yanindaki kilisede hakim Eflâtun'un mezarl vardır" diye bahseder. Coğrafya bilgini Yâkūt el-Hamevî de (ö. 626/1229) Mu 'cemü'l-büldân adlı eserinde Herevî'yi kaynak göstermek suretiyle bu bilgiyi yinelemiştir. Mehmed b. Ömer el-Âşı1̄i de (ö.1006/1598) Menâzırü'l-avâlim isimli eserinde Konya'dan söz ederken, "Buranın kalesinde Eflâtun'un kabri vardır” ifadesini kullanmışıı ${ }^{30}$. Konyalı'nın naklettiği bilgilere göre, Müneccimbaşı Ahmet Dede (ö.1113/1702) ve Kâtip Çelebi (ö.1067/1657) Eflatun’un kabrinin Konya’da olduğunu, tarihçi Hammer

27 İsmail Taş ile 08.08.2020 tarihinde yapılan görüşme kayıtları.

28 Alıc1, "Sühreverdî’nin İşrâk Düşüncesini İnşâda Kadim Etimolojilerin Yeri”, 76.

29 Konyal, Konya Tarihi, 1090.

30 Semavi Eyice, "Eflatun Mescidi”, Türkiye Diyanet Vakfi İslâm Ansiklopedisi, c. 10 (İstanbul: Türkiye Diyanet Vakfi Yayınları, 1994), 477. 
ise Konya'da doğduğunu söylemektedir ${ }^{31}$. Suzan Yalman, Eflâtun mezarının yanı sıra, Sille'deki "Eflâtun Manastırı" ve Beyşehir Gölü yakınlarındaki "Eflâtun Pınarı" gibi filozofla ilişkilendirilen yapıların bir rastlantıdan ziyade bir kültün parçası olduğunu, Eflâtun'a Konya şehrinin "azizi” gibi bir kutsal kimliğin kazandırıldığını ifade eder ${ }^{32}$. Bu bilgilerin sıhhati konusunda şüpheler olsa da Eflatun ile Mevlânâ’nın düşüncelerinin bazı noktalarda kesişmesi ve iki düşünür arasındaki yakınlıktan dolayı söz konusu mekân teberrüken Eflatun adına isimlendirilmiş olabilir. Nitekim kültürümüzde toplum tarafından sevilen ve makbul görülen bazı önemli şahsiyetlerin defnedildiği aslî kabirleri dışında, saygı ve sevgiden dolayı farklı alanlarda onlar adına makam veya sanduka yaptırılmıştır. Yunus Emre bunun en güzel örneklerinden biridir.

Selçuklu döneminde şehir merkezi ile Sille arasındaki Akmanastır diye adlandırılan alanın Selçuklu kaynaklarında Deyr-i Eflâtun olarak ${ }^{33}$ anılması, Hitit çağından beri kutsallık izafe edilen pınarın "Eflâtun pınarı" diye isimlendirilmesi Konya ve Eflatun bağlantısının çok eskilere dayandığını göstermektedir ${ }^{34}$. Yukarıda bahsettiğimiz şekilde Eflatun ile Mevlânâ arasındaki felsefi bağlantıdan türbe yüzeylerinde bulunan resimlerde Eflatun'u hatırlatan bir figürün uygulanmasını normal görebiliriz.

\section{Kandil}

Tasvirlerde bazen birkaç unsurun stilize edilerek resmedilmesi, eseri bir araya getiren uzun bir gözlem ve tasarım aşamasının ürünüdür. Tasvirlerde bulunan bazı ögeler burada anlatılmak istenen felsefi düşüncenin resmedilmesi şeklinde karşımıza çıkabi$\operatorname{lir}^{35}$. Söz konusu resimlerde yer alan mimari yapılar dışında, bunlar üzerinde bulunan ve dikkat çeken bazı motifler vardır. Bunlardan biri kandil, diğeri ise perde motifidir (G.2,7,8). Kuzeybatı filpâyenin doğu cephe yüzeyinde yer alan resimdeki kandil motifi önemlidir (G.8.). Kandil nurdur, aydınlanmadır. İşrakîye'nin kurucusu Sühreverdî "ruhî arınmayı esas aldı̆̆ l felsefesinde ontik varlığı nur kavramıyla açılklar" ${ }^{36} . \mathrm{Bu}$ âlemdeki düzen, nur âleminin bir yansımasıdır. Bu âlem, nurlar âleminin bir kopyasıdır ancak nurlar âlemindeki düzen daha tam ve daha mükemmeldir. Her bir nurun muhabbet, hâkimiyet, lezzet vb. nurlu heyetleri bu âlemdeki gölgesine misk kokusu, tat gibi özellikler olarak akseder Sühreverdî’nin nur metafiziği düşüncesinde Kur'an'daki Nûr Sûresinin 35. ayetinde "Allah göklerin ve yerin nurudur" âyeti, bir ilham kaynağı olmuştur. Burada insan ne kadar aydınlanırsa o kadar aydınlatır ve kendini de o

31 Konyalı, Konya Tarihi, 351-352.

32 Yalman, “Platondan Şehname’ye; Selçuklu Dönemi Konya’sında Aziz Ziyaretleri Üzerine Düşünceler, 120.

33 Konyal1, Konya Tarihi, 123. 1083.

34 Eyice, "Eflatun Mescidi", 10/477.

35 Çiğdem Önkol Ertunç, "Kelile ve Dimne Minyatürlerinin Anlatımsal Açıdan İncelenmesi”, Biltek Uluslararası Bilim, Teknoloji ve Sosyal Bilimlerde Güncel Gelişmeler Sempozyumu Tam Metin Kitabl "Sosyal ve Beşeri Bilimler”, ed. Prof. Dr. Abdulhamit Sinanoğlu, Prof. Firoz Faozi (Ankara: İKSAD, 2019), 1:411-426. 36 Kaya, Işrâkıyye, 23/435-438. 
nispette bilir düşüncesi hâkimdir. Zira "herhangi bir şeyi bilmek için bir kimsenin ilk önce kendi nefsini bilmesinin gerekli olmast” Aristo'nun Sühreverdî’ye rüyasındaki tavsiyesidir ${ }^{37}$. Mevlânâ'nın "efendi sen kendinden kendine sefer et kendinde kendini ara"38 tavsiyesi de aynı şekilde insanın kendini bilmesine yöneltmektedir. Kandil metaforunun bu anlamda hem tepenin altındaki Kubbe-i Hadrâ olarak tavsif ettiğimiz binada hem de tepenin üzerindeki Eflatun Mescidi olarak tanımladığımız binada kullanılması bu tezimizi güçlendirmektedir.

\subsection{Perde}

Mimari yapılar üzerinde dikkat çeken motiflerden bir diğeri perde motifidir. Güneydoğu ve kuzeydoğu filpayenin üzerinde bulunan resimlerde perde tasvirinin olduğu muhkem bir yapılar söz konusudur (G.2, G. 7). Perde gizlilik ve mahremiyeti ifade eder. Dünya ile bir bağlantı olduğu için perde resmedilmiştir. Sühreverdî'nin felsefesinde "hads ve keşfin meydana gelebilmesi için mutlak olanla aradaki bütün varlık perdelerinin ortadan kalkmasinin gerekli olduğu" ifade edilir. Aristo rüyasında Sühreverdî’ye "bu âlemde kaldığınız sürece perdeler ardında kaldınız demektir. Her ne zaman ki kemaliyle bu âlemden yükseldiniz işte o zaman ittisal (Bitişme) ve ittihad (Birleşme) söz konusu olabilir" dediğini açıklamışıır ${ }^{39}$. Burada ifade edildiği şekilde perde motifi yükselmenin ve ilerlemenin de ölçütü olarak değerlendirilmiştir. Söz konusu bu tabloyu son merhale, kemal noktası olarak okumak mümkündür.

\section{Nebati Tasvirler}

Nebati tasvirler içerisinde başta servi ağacı olmak üzere, bahar dalları, süsen çiçeği, hindiba ve ot kümeleri dikkat çeker. Servi ağacı, ölümün sembolü olarak bilinir. Bahar dalları ve çiçekler ise yenilenme, tazelenme anlamına gelir. Musavvir servi ve bahar dallarının birlikteliği ile hayatın akışını, yaşam ve ölümü, bunların birbirinden ayrılamayan gerçekler olduğunu işlemiş olmalıdır.

\subsection{Servi Ağacı}

Hemen her tabloda simetrik olarak yer alan ağaç figürleri vardır. Ağaç, çiçeği, meyvesi ve diğer estetik özelliklerinin yanında, insanların beşikten mezara kadar hayatın her safhasında kullandığı bir malzemedir. Ağaçların mevsimler dahilinde görünümlerinin değişmesi, kış mevsiminde yapraklarını dökmesi, bahar mevsiminde yeniden canlanarak hayat bulması, ölümden sonraki dirilişin, ebedi hayatın varlığının, yeniden canlanmanın, evrendeki değişimin bir sembolü olarak değerlendirilmiştir ${ }^{40}$. Her top-

37 Çatak, Sühreverdi'nin Felsefi Tasavvurunda Marifet, 202.

38 Şefik Can, Mevlânâ ve Eflatun, 32.

39 Çatak, Sühreverdi'nin Felsefi Tasavvurunda Marifet, 201.

40 Hikmet Tanyu, “Ağaç”, Türkiye Diyanet Vakfi İslâm Ansiklopedisi, c.1 (İstanbul: Türkiye Diyanet Vakfi Yayınları, 1988), 456-457. 
lumda ve inançta ağaca bir anlam yüklenmesi, ona kutsallık izafe edilmesi, toplumlarda ağaç kültünün oluşmasına sebep olmuştur ${ }^{41}$. Kur'an-1 Kerim’de çeşitli vesilelerle kırk kadar yerde nebati nimetler olan çeşitli bitkiler, meyveler ve ağaçlardan bahsedilmiştir. Ağaç kavramı insanlara mesajını iletmek için kullanılan vasıtalar arasında yer alır. Söz konusu bitki ve meyvelerin insanlara yemek için, ateş yakmak için ve cennet ehline mükâfat olarak karşılaşacakları birer nimet olarak verildiğinden bahsedilir ${ }^{42}$.

Resimlerde görülen servi ağacı geleneğimizde insan hayatının doğumdan ölüme kadar var olma çabalarının, cennetteki ebedi hayatın, vahdetin sembolü olarak kullanılmıştır. Bütün mevsimlerin zorlu koşullarına rağmen yeşilini hiç kaybetmeyerek güçlü kalması ya da dikey oluşu ve bu şekilde gelişip büyümesi (ölüm ve yükselme) ve dayanıklılı̆̆1, hayatı tasvir eder ${ }^{43}$. Servi ağacı rüzgârın tesiriyle "Hû " sesini çıkardığ 1 düşünüldüğü için kabristanlarda fazlaca görülür ${ }^{44}$. Ölümü ve faniliği, vahdeti ve tevhidi simgeleyen bir sembol olarak değerlendirilen servi ağacı Osmanlıda hayat ağacı olarak da tanınmıştır ${ }^{45}$. Bundan dolayı Osmanlı mezar taşlarında çok karşılaştığımız bir motiftir. Mesnevi'nin pek çok yerinde servi ağacına atıflar yapılmıştır:

\footnotetext{
"Selviye bir şey yaptr. Boyunu dümdüz etti... Nergisle ağustos gülü de ondan feyz aldl, güzelleşti. 3/ 4130"46

"Yahut Tanrı, seni o âlemde bir servi yapsin da ebediyen terü taze kal” dedi. 1/2117"47

"Selvilerle yeşillik, daima dilsiz, dudaksız olarak suya ve ilkbaharın adaletine şükredip durmadadır. 6/ 4544"48
}

\subsection{Bahar Dalları}

Bahar dalı motifi, baharı ve baharın getirdiği güzellikleri simgeler. Meyve vermiş bir ağaç olarak yapılan tasvirlerde bu ağacin esasında hangi meyvenin ağacı olduğunu söylemek mümkün değildir ${ }^{49}$ Ağaçların meyveli değil çiçekli olarak tasvir edilmesi yaşama duygusunu aşılayan bir yaklaşımdır. Tablolarda yer alan servi ağaçlarının çevresi bahar dalları ile kuşatılmıştır. Bu tasvirden yukarıda da bahsettiğimiz şekilde hayatın ve ölümün iç içe olmasını servi ağaçlarında çiçeklerin bulunmasını da

41 Müjgân Üçer, Türk Kültür ve Sanatında Hayat Ağacı (Ankara: Atatürk Kültür Merkezi Yayınları, 2019 ), 6.

42 Nihat Uzun, “Kur'ân’da Üç Ağaç Türü Yahut Bazı Âyetlerin Anlamlarını Yeniden Düşünmek”, Dinbilimleri Akademik Araştırma Dergisi 11/3 (2011), 133-164.

43 Recep Kankal, “Türk Kültüründe Servi Ağacı, Cypress Tree in Turkish Culture”, Türkiye 'nin Kültür Dergisi Culture Magazine of Turkey 11(2016), 50-57; Mircea Eliade, Dinler Tarihi Ínançlar ve İbadetlerin Morfolojisi, çev. Mustafa Ünal (Konya: Serhat Kitabevi, 2005), 337.

44 İskender Pala, Ansiklopedik Divan Şiiri Sözlüğü (Ankara: Kapı Yayınları, 2018), 414.

45 Üçer, Türk Kültür ve Sanatında Hayat Ağacı, 56.

46 Mesnevi, 3/337.

47 Mesnevi, 1/169.

48 Mesnevi, 6/361.

49 Yıldız Demiriz, Osmanlı Kitap Sanatında Natüralist Üslupta Çiçekler (İstanbul: Edebiyat Fakültesi Yayınları, 1986), 335. 
ölümsüzlük temasının işlendiğini görebiliriz. Zira Allah önce ölümü sonra hayatı yaratmıştır. ${ }^{50}$ Burada Türk kültüründe yer alan "Uçmak" kavramını da değerlendirebiliriz. Bilge insanların aydınlanmaları anlamına gelen uçmak, varlık zincirinden kopan insanın durumunu anlatan en güzel terim olarak adlandırılmaktadır ${ }^{51}$. Uçmak aynı zamanda cennet anlamına gelir. Ayrıca 5. tabloda kırılan bir dal vardır (G. 7). Dalın kırılması yükselmeye engel teşkil etmektedir ve bir kayıp söz konusudur. Yüksek mertebelere ulaşmak istenilen bu süreçte elbette yükselemeyenler de olacaktır. Her insanın her zaman yükselemeyeceği sembolize edilmiş olmalıdır. Ağaçların çiçeklerin, çiçekli dalların resmedilmesinde cennet tasvirlerinin olduğu muhakkaktır. Zira Kur'an-1 Kerim'de “Ăgaçları; sarmaş dolaş olmuş bağlar ve bahçeleri de meydana getirdik ${ }^{52}$ " buyrulmaktadır. Ağaç tasvirlerinden "Şeceretü' $l$ - kevn" yani Varlık Ağac1 kavramını da göz ardı etmemek gerek.

\section{3. Şeceretü'l - Kevn}

Varlık ağacı bütün varlığın ağaç sembolü üzerinden anlatılmasını ifade eden bir terimdir ${ }^{33}$. İbn Arabî, Şeceretü'l-Kevn adl1 eserinde bu konuyu şöyle ifade eder: “Gördüm ki, bütün Kâinât tümden bir ağaçtan ibâret ... O ağacın asll nûru ise; "Kün! Yani Ol!" tohumundan meydana gelmiştir ${ }^{54}$. Bu hususu aynı zamanda Hz. Peygamberle yani Hakikat-ı Muhammediye ile ilişkilendirebiliriz. "Çekirdeğin içinde dallarlyla, yapraklartyla, çiçekleriyle, meyveleriyle beraber bir ağaç vardır. Bu ağaç kuvvededir, henüz fiile intikal etmemiştir. Çekirdek içinde var olan bu ağaç, o çekirdeğin aynıdır. Varlığın aynı Hakikat-ı Muhammediye'de mevcuttur ${ }^{55}$ ".

Resimlerde yer alan ağaçların biçimlerinde ve yapraklarında karmaşıklık söz konusudur. $\mathrm{Bu}$ betimlemeyle hayatın kargaşası ortaya konulmuş olsa da neticede ağaç meyvesi için vardır. Meyveler de insana hizmet içindir. Meyve sembolünde Hakikati Muhammediye tasvirini de düşünebiliriz ki, buna göre Hz. Muhammed (sav) kâinat ağacının en üstün meyvesidir.

\footnotetext{
"Tasavvufta; dünya bir bahçeye benzetilirken, insan ă̆aca, diğer canlllar bu ă̆acın yapraklarına benzetilmiştir. Hz. Muhammed (sav) dışındaki diğer peygamberler ağacın meyvelerine, Hz. Peygamber (sav) de o meyvelerin özüne, çekirdeğine benzetilmiştir. Tabiatıyla çekirdek ekildiği zaman, fidan olur, ardından ă̆aç olur ve meyve vermeye
}

50 Kur'an-ı Kerim Meâli (Ankara: Diyanet İşleri Başkanlığı 2007), Mülk Sûresi 67/2.

51 İsmail Taş, “Türk Düşüncesinin Bazı Temel Kavramları ve Türk Aydınlanmasının Kaynaklarına Dair”, Türk Düşüncesi 5 (2020), 59-73.

52 Nebe Sûresi, 78/16

53 H. Mahmut Yücer ve Sedat Küçük, “Tasavvuf Literatüründe Ağaç Sembolizmi ve Muhyî’nin Temsîl-i-Şecer İsimli Eseri”, Akademik Platform İslami Araştırmalar Dergisi 3/1 (2019), 15.

54 Muhiddin-i Arabi, Şeceret ’ül-Kevn Üstün İnsan, çev. Abdulkadir Akçiçek (İstanbul: Rahmet Yayınları, 1982$), 10$. 55 Yücer ve Küçük, “Tasavvuf Literatüründe Ağaç Sembolizmi ve Muhyî’nin Temsîl-i-Şecer İsimli Eseri”, 17. 
başlar. Bu meyve sonunda tekrar özüne yani çekirdeğe döner ki, Hz. Peygamber (sav) meyve-çekirdek anlatımıyla onun evvel-âhir oluşunu ifade eder. "'56

Bu olayı Mevlânâ Mesnevi'de şu şekilde anlatır:

"Görünüşde dal, meyvanın aslıdır; fakat hakikatte dal meyva için var olmuştur. Meyva elde etmeğe bir meyli, meyva vermeğe bir ümidi olmasaydı hiç bahçıvan, ă̆aç diker miydi? Şu halde meyva, görünüşte ă̆açtan doğmuştur ama hakikatte ă̆aç, meyvadan vücut bulmuştur. Mustafa, onun için "Âdem'le bütün peygamberler, benim ardımda ve sancağımın altındadır" dedi. 4/522-525" diye anlatır. Beytin devamında "Sûret bakımından ben Âdem'den doğmuşum ama hakikatte onun atasının atasıyım ben! Melekler, bana secde ettiler... Âdem, benim ardımdan yürüdü, yedinci kat gögün üstüne çıktı! Hakikatte babam, benden doğdu... Ağaç, meyvadan vücud buldu." 4/ 527"57.

Sonuç itibariyle meyve metaforuyla bütün âlem Hakîkat-i Muhammediye’nin özü olarak görülmektedir.

\subsection{Süsen- Zambak}

Ölümü simgeleyen süsen çiçeği, zambak veya iris olarak da adlandırılmaktadır. Süsen çiçeğinin mezarlıklarda yetişiyor olması sebebiyle mezarlık kültürümüzde önemli bir yeri vardır ${ }^{58}$. Türk kültüründe mezar çiçeği olarak da bilinir. Pek çok aydınlanma ve yükselme sembolizminin kullanıldığı resimlerde sıklıkla süsen çiçeğinin kullanılıyor olması, insanoğlu için dünya hayatının yanı sıra ahiret hayatının varlığının da hatırlatması olarak değerlendirilebilir.

Süsen'in Mesnevi' de ilahî bilgi, kâmil insan ve cennet gibi kavramları sembolize ettiği görülür:

\footnotetext{
"Gamdan neşe artmaya başladı mı can bahçen güllerle, süsenlerle dolar. 2/1379"59,

"Ey inananlar, sevinin. Selvi gibi, süsen gibi hür olun. 6/4542"

"O orman, süsenlerle, reyhanlarla, güllerle, yenmesi hoş meyva ağaçlarıyla doluydu. $6 / 4808 " 61$.

"Beni selvi ve süsen gibi azat etti. Bahtım, devletim gibi gönlüm de açıldı. 5/2309"62 beytinde ise servi ve süsen birlikte anılmaktadır.
}

\footnotetext{
56 Yücer ve Küçük, “Tasavvuf Literatüründe Ağaç Sembolizmi ve Muhyî’nin Temsîl-i-Şecer İsimli Eseri”, 19. 57 Mesnevi, 4/43.

58 Deniz Gezgin, Bitki Mitoslarl (İstanbul: Sel Yayınc1lı, 2015), 173.

59 Mesnevi, 2/105.

60 Mesnevi, 6/361.

61 Mesnevi, 6/382.

62 Mesnevi, 5/328.
} 


\subsection{Hindiba}

5. tabloda diğer nebati motiflerden farklı olarak hindiba resmedilmiştir (G.7). Hindiba farklı kültürlerde de mitolojik olarak pek çok anlam ifade etmektedir. Yahudilerde "Fisıh Bayramı" yani bahar bayramında ikram edilen "seder" adı verilen özel yemekte acıyı ve zorluğ ${ }^{63}$ simgelerken aynı şekilde Yunan mitolojisinde güneşi sembolize etmektedir. Dolayısıyla bitkinin burada kullanılması insanları karanlıktan ve zorluktan nura yani aydınlığa kavuşturması diğer bir deyişle “işrak” aydınlanma felsefesi ile bağlantılı olabileceğini düşündürmektedir. Bir başka açıdan değerlendirilecek olursa pek çok ölüm ve mezar sembolizminin yer aldığg tasvirlerde bulunan hindiba çiçeği benliğin ve nefsin terbiye edilerek yani temizlenerek bu yüksek nurları kavrayacak duruma gelmesini ifade eder. Peygamber Efendimizin (S.A.V) bir hadis-i şerifinde; "Hindibanın her bir yaprağl, üzerinde Cennetten bir katre bulunur" buyurduğu rivayet edilir ${ }^{64}$. Netice itibariyle bedeni marazların temizlenmesinde önemli rol oynadığ1 söylenen hindiba bitkisi tasavvufi gerçeklerin kavranmasının, benliğin temizlenmesinin, nura yönelmenin ifadesi olarak kullanılmıştır.

\section{Renkler}

Resimlerde kullanılan nebati tasvirlerden sonra bu tasvirlerde kullanılan renklere de kısaca göz atmak yerinde olacaktır. Çünkü nebati tasvirlerde kullanılan renklerin ifade açısından muhataplara karşı etkilerinin olduğunu düşünmek, böyle felsefi bir değerlendirmenin olduğu resimlerde hiç de göz ardı edilecek bir durum değildir. Özellikle İşrakîlik bağlamında nurun, yani 1şığın, rengin ve gölgenin önemi büyüktür. Meseleye bu açıdan baktığımızda nebati tasvirlerde kullanılan renklerin kendileri gibi sembolik ifadeleri bulunmaktadır. Zira renk ve renkler tarihin en eski dönemlerinden bu yana varlıkları tanıma ve sınıflandırmada en çok yararlanılan unsurlarından biri olmuştur ${ }^{65}$. Tasvirlerde kırmızı, beyaz, siyah ve yeşil renkler kullanılmıştır. "Işı̆ğın yaratıcı sürecini özetleyen temel palet beyaz, siyah ve kırmızıdan oluşmuştur. Bu renkler Kur'an-ı Kerîm'de 66 , “Allah'ın gökten su indirdiğini görmez misin? Sonra onunla renk ve çeşitleri farklı ürünler çıkardık. Dağların da farklı renklerde; beyaz, kırmızı, simsiyah yolları, kısımları vardır"67 ayetindeki renklerin sunduğu dizilim işaret edilmektedir ${ }^{68}$.

Nebati tasvirlerde kullanılan beyaz renk, mitolojik olarak aydınlık, 1şık ve güneşin yanı sıra kutsallığın, ruhsal yetkinliğin, temizliğin, iffetin ${ }^{69}$, yüceliğin, büyüklüğün ve

63 Gezgin, Bitki Mitoslarl, 173.

64 Ahmed Ziyauddin Gümüşhânevî, Râmûz el-Ehâdis (İstanbul: Milsan Basım, 1982), 318.

65 Akın Kanat, Renk ve Duyu Psikolojisi (İzmir: İlya Yayınevi, 2001), 147.

66 Cabrera, İşrak, 90.

67 Fâtır Sûresi 35/27.

68 Cabrera, Isşrak, 90.

69 Yaşar Çoruhlu, Türk Mitolojisinin Anahatları (İstanbul:Kabalcı Yayınları, 2000), 190. 
iyiliğin sembolüdür ${ }^{70}$. Yükselme, kutsiyet alma gibi önemli sembolik ifadeleri olan beyaz rengin 1şı̆̆ı sembolize ederek aydınlanmayı anlatması Sühreverdî felsefesi ile paralellik göstermesi dikkat çekicidir.

Kur'an'da pek çok ayette yer alan beyaz renk ${ }^{71}$, ahirette yüzlerin ağarması, müminlerin sevinmesi gibi ifadelerle iyiliği sembolize eder. Musa peygamberin "beyaz el" mucizesi de yine beyaz renk için güzel bir örnektir ${ }^{72}$.

Bahar dallarının gövdelerinde kırmızı tonlar kullanılmıştır. Kırmızı renge tarihin her döneminde çeşitli anlamlar yüklenmiştir. Genel olarak, güneşi, ateşi, aşkı ve hazzı, gücü simgeleyen ${ }^{73}$ kırmızı, mutluluğun ve canlılığın yani kanın rengidir. Yeryüzünde can taşıyan her şeyin hayatiyeti kana bağlıdır ${ }^{74}$. Özellikle bahar dallarının gövdelerinin kırmızı tonlarda resmedilmesi burada ümidi ve yaşamayı simgeleyen bu ağacın hayat ile bağdaştııılmasının göstergesidir. Hashim Cabrera, İşrakîlik bağlamında renge dair görüşlerini ifade ederken kırmızı rengin dar anlamda tüm renklerin örneklemi olduğunu ve kırmızının özel yoruma dayanan bir geleneğe sahip bulunduğunu ifade etmektedir ${ }^{75}$.

Yeşil her zaman doğa kültü dolayısıyla hayat ağacı figürü ile ilgilidir ${ }^{76}$. Tasvirlerde kullanılan yeşil renk tabiatın rengini, canlılığ , ahengi ve güzelliği sembolize eder. Kuru ve ölü topraktan çıkan ilk şey yeşil bir örtüdür. Yeşil insanoğlunu bütün renklere hazır hâle getiren bir renktir ${ }^{77}$. İşrakî felsefenin temelini teşkil eden Nûr Sûresi'nde geçen "bu kandil doğuya da batıya da ait olmayan, yağı neredeyse ateş dokunmasa bile ışık veren mübarek bir zeytin ağacından yakılır"78 beyanı aynı zamanda yeşil rengin özelliğini anlatmaktadır. Tarikat ehli insanların kıyafetlerinde yeşil rengin kullanılması bu rengin bir sembolik değerinin olduğu sonucunu çıkarmaktadır ${ }^{79}$.

\section{Sonuç}

2018 yılında gerçekleştirilen restorasyonda gün yüzüne çıkarılmış olan ve öncelikle teknik açıdan, ardından da felsefi sembollerle açıklamaya çalıştığımız bu tasvirler mutlak anlamda derin bir düşüncenin ürünüdür. 2. Bayezid döneminde yapıldığını

70 Bahaeddin Ögel, Türk Kültür Tarihine Giriş Türklerde Tuğ ve Bayrak (Hunlardan Osmanlılara) (Ankara: T.C. Kültür Bakanlığı Yayınları, 2000), 6/381.

71 Âl-i İmrân 3/ 107, Şuara Sûresi 26/33, Neml Sûresi 27/12.

72 Ömer Faruk Harman, "Yed-i Beyzâ", Türkiye Diyanet Vakfi İslâm Ansiklopedisi, c. 43 (Ankara: Türkiye Diyanet Vakfi Yayınları, 2013), 376-377.

73 Çoruhlu, Türk Mitolojisinin Anahatları, 186.

74 Abdulmecit.Okcu, “Kur'an'da Renkler”, Atatürk Üniversitesi İlahiyat Fakültesi Dergisi 28 (2007), 127-163.

75 Cabrera, İşrak, 91.

76 Çoruhlu, Türk Mitolojisinin Anahatları, 186.

77 Cabrera, İşrak, 165.

78 Nûr Sûresi, 24/35

79 Okcu, “Kur'an'da Renkler”, 152. 
düşündüğümüz ve ne zaman ve kimler tarafından üzerlerinin kapatıldığını bilemediğimiz bu resimler tezyinat tarihimiz açısından önemli örneklerdir. Söz konusu resimler bulundukları konumları itibariyle titiz şekilde tarafımızdan incelenmiş, dikkat çeken kandil figüründen ve Eflatun Mescidi'nden yola çıkarak Eflatun, İşrakîlik, Mevlevilik gibi birbirleri ile etkileşimli düşünce sistemleri üzerinden bir değerlendirilme yapılmıştır. Her ne kadar resimler konusunda elimizde herhangi bir kaynak veya belge olmasa da İslam felsefesi ve Mevlânâ konusunda yaptığımız araştırmalar ve konunun uzmanları ile yaptığımız detaylı görüşmeler bizim düşüncemize büyük katkı sağlamıştır. Sembollerle ifade edilmeye çalışılan düşüncelerin büyük mütefekkir Mevlânâ'nın türbesinde yer alması elbette önem arz eder. Bu konuyu Murat Özer, semboller üzerinden manayı ifade eden medeniyet, "yaşayan organizma olan toplumu” hem geçmişi ile bağlı hem de geleceğine dair arayışa meyyal bir terazide tutmayı başarmıştır ${ }^{80}$ " cümlesiyle en güzel şekilde özetlemektedir. Öte yandan Müstakim Arıcı'nın “'Osmanlı İlim Dünyasında İşrâkî Bir Zümreden Söz Etmek Mümkün mü? Osmanlı Ulemasının İşrâkîlik Tasavvuru Üzerine Bir Tahlil" başlıklı makalesinde yer alan "İşrâkî yorumların edebiyatta ve sanatta nasıl bir karşılık bulduğu ayrıca irdelenmeye değer ve buralar şimdilik bizim için tamamen meçhul alanlar olmaya devam ediyor. Sembolik tarafları olan bu felsefenin tezhip ve özellikle minyatür sanatlarında, cami, tekke, medrese gibi yapıların mimarisinde bile izlerinin bulunduğu varsayımı da araştırılmayı hak ediyor ${ }^{81}$ şekindeki tespiti de cevabını bulmuş olacaktır.

Hakem Değerlendirmesi: Dış bağımsız.

Çıkar Çatışması: Yazar çıkar çatışması bildirmemiştir.

Finansal Destek: Yazar bu çalışma için finansal destek almadığını beyan etmiştir.

Peer-review: Externally peer-reviewed.

Conflict of Interest: The author has no conflict of interest to declare.

Grant Support: The author declared that this study has received no financial support.

\section{Kaynakça/References}

Alıc1, Mehmet. "Sühreverdî’nin İşrâk Düşüncesini İnşâda Kadim Etimolojilerin Yeri.” Milel ve Nihal 11/2 (2014): 61-81.

Arıc1, Mustakim. "Osmanlı İlim Dünyasında İşrâkî Bir Zümreden Söz Etmek Mümkün mü? Osmanlı Ulemasının İşrâkîlik Tasavvuru Üzerine Bir Tahlil.” Nazariyat 4/3 (2018): 1-48.

Baysal, Ali Fuat ve Ayşe Zehra Sayın. "Restorasyon Sonrası Kubbe-i Hadrâ Kalem İşleri Üzerine Değerlendirme.” ISTEM Dergisi 33 (2019): 39-6.

Baysal, Ali Fuat. Kubbe-i Hadrâ Kalemişi Tezyînâtı ve Onarımı. Konya: Palet Yayınları, 2020.

Cabrera, Hashim. İşrak, Ruhun Renkleri. Çev. İbrahim Aybek. İstanbul: Hece Yayınları, 2019.

80 Murat Özer, Türk Dünyasında 'Mevlevilik've 'Sanat' Yansımalarl, 189.

81 Mustakim Arıcı, “Osmanlı İlim Dünyasında İşrâkî Bir Zümreden Söz Etmek Mümkün mü? Osmanlı Ulemasının İşrâkîlik Tasavvuru Üzerine Bir Tahlil”, Nazariyat 4/3 (2018), 43. 
Can, Şefik. Mevlânâ ve Eflatun. İstanbul: Okul Yayınları, 2004.

Cihan, A. Kamil. "Sühreverdî ve İşrâkîlik". İslâm Felsefesi Tarih ve Problemler. Ed. Cüneyt Kaya. İstanbul: Türkiye Diyanet Vakfi Yayınları, 2018, 397-427.

Çatak, Âdem. "Sühreverdî’nin Felsefi Tasavvurunda Marifet”. Sühreverdî ve İşrak Felsefesi. Ed. M. Nesim Doru, Kamuran Gökdağ, Yunus Kaplan. Ankara: Otto Yayınları, 2015, 187-227.

Çoruhlu, Yaşar. Türk Mitolojisinin Anahatları. İstanbul: Kabalcı Yayınları, 2000.

Demiriz, Yıldız. Osmanlı Kitap Sanatında Natüralist Üslupta Çiçekler. İstanbul: Edebiyat Fakültesi Yayınlar1, 1986.

Eliade, Mircea. Dinler Tarihi İnançlar ve İbadetlerin Morfolojisi. Çev. Mustafa Ünal. Konya: Serhat Kitabevi, 2005.

Erdoğan, İsmail. "İşrâkîlik'in İslâm Felsefesi İçerisindeki Yeri ve Kaynakları”. Fırat Üniversitesi Ilahiyat Fakültesi Dergisi 8 (2003): 159-178.

Ertunç, Çiğdem Önkol. “Kelile ve Dimne Minyatürlerinin Anlatımsal Açıdan İncelenmesi”. Biltek Uluslararası Bilim, Teknoloji ve Sosyal Bilimlerde Güncel Gelişmeler Sempozyumu Tam Metin Kitabı. 1. cilt. Ed. Abdulhamit Sinanoğlu ve Firoz Faozi. Ankara: IKKSAD, 2019, 411-426.

Eyice, Semavi. "Eflatun Mescidi”. Türkiye Diyanet Vakfi İslâm Ansiklopedisi. 10. İstanbul: Türkiye Diyanet Vakfi Yayınları, 1994, 477.

Gezgin, Deniz. Bitki Mitosları. İstanbul: Sel Yayıncılık, 2015.

Gümüşhânevî, Ahmed. Ziyauddin. Râmûz el-Ehâdis. İstanbul: Milsan Basım, 1982.

Harman, Ömer Faruk. "Dağ", Türkiye Diyanet Vakfi İslâm Ansiklopedisi. 8. İstanbul: Türkiye Diyanet Vakfi Yayınları, 1993, 400-401.

Harman, Ömer Faruk. "Yed-i Beyzâ". Türkiye Diyanet Vakfi İslâm Ansiklopedisi. 43. İstanbul: Türkiye Diyanet Vakfi Yayınları, 2013, 376-377.

İrteş, Semih. "Mevlânâ Türbesi Kubbe-i Hadra Kalemişi Restorasyonunda Yeni Buluntular". Lale Kültür Sanat ve Medeniyet Dergisi 1 (2020): 6-21.

Kanat, Akın. Renk ve Duyu Psikolojisi. İzmir: İlya Yayınevi, 2001.

Kankal, Recep. "Türk Kültüründe Servi Ağacı, Cypress Tree in Turkish Culture”. Türkiye'nin Kültür Dergisi 11 (2016): 50-57.

Kaya, Mahmut. "İşrâkıyye”. Türkiye Diyanet Vakfi İslâm Ansiklopedisi. 23. İstanbul: Türkiye Diyanet Vakfi Yayınları, 2001, 435-438.

Konyal1, İ. Hakk1. Âbideleri ve Kitabeleriyle Konya Tarihi. Konya: Enes Kitap Saray1, 1997.

Kur'an-ı Kerim Meâli. Ankara: Diyanet İşleri Başkanlığı, 2007.

Kuşpınar, Bilal. Isma'il Ankaravi on the Illuminative Philosophy. Kuala Lumpur: International Institute of Islamic Thought \& Civilization (ISTAC), 1996.

Kuşpınar, Bilal. “İsmail Ankaravî’nin İşrâkî Felsefesi Yorumu”. Osmanlı ve İran'da İşrâk Felsefesi. Ed. M.N. Doru, Ö. Bozkurt, K. Gökdağ, M. F. Kılıç. İstanbul: Divan Yayınları, 2018, 49-64, 208.

Mesnevî. Ed. Abdülbaki Gölpınarlı. Çev. İzbudak, Veled Çelebi. İstanbul: Milli Eğitim Bakanlığı Yayınlar1, 1990.

Muhiddin-i Arabi. Şeceret'ül-Kevn - Üstün İnsan. Çev. Abdulkadir Akçiçek. İstanbul: Rahmet Yayınları, 1982.

Okcu, Abdulmecit. “Kur'an'da Renkler”. Atatürk Üniversitesi İlahiyat Fakültesi Dergisi. 28 (2007), 127-163. 
Okudan, Rıfat. "İşrak Filozofu Sühreverdî Maktûl ve Eserlerindeki Üslup ve Belağat”. Doktora Tezi, Süleyman Demirel Üniversitesi, 2001.

Ögel, Bahaeddin. Türk Kültür Tarihine Giriş Türklerde Tuğ ve Bayrak (Hunlardan Osmanlılara). C. 6. Ankara: T.C. Kültür Bakanlığı Yayınları, 2000.

Özer, Murat. Sikkenin Altındaki Sanat, Türk Dünyasında 'Mevlevilik' ve 'Sanat' Yansımaları. Eskişehir: Türk Dünyası Vakfi, 2013.

Pala, İskender. Ansiklopedik Divan Şiiri Sözlüğü. Ankara: Kapı Yayınları, 2018.

Tanyu, Hikmet. “Ağaç”. Türkiye Diyanet Vakfi İslâm Ansiklopedisi. 1. İstanbul: Türkiye Diyanet Vakfi Yayınları, 1988, 456-457.

Taş, İsmail. “Türk Düşüncesinin Bazı Temel Kavramları ve Türk Aydınlanmasının Kaynaklarına Dair”. Türk Düşüncesi 5 (2019): 59-73.

Uzun, Nihat. “Kur'ân'da Üç Ağaç Türü Yahut Bazı Âyetlerin Anlamlarını Yeniden Düşünmek”. Dinbilimleri Akademik Araştırma Dergisi 11/3 (2011): 133-164.

Üçer, Müjgân. Türk Kültür ve Sanatında Hayat Ağacı. Ankara: Atatürk Kültür Merkezi Yayınları, 2019.

Yalman, Suzan. "Platondan Şehname’ye; Selçuklu Dönemi Konya'sında Aziz Ziyaretleri Üzerine Düşünceler.” Kutsal Mekanlar ve Kentsel Ağlar. Ed. A. H. Uğurlu ve S. Yalman. İstanbul: ANAMED, 2019, 119-40.

Yörükan, Yusuf Ziya. Şihabeddin Sühreverdî ve Nur Heykelleri. İstanbul: İnsan Yayınları, 1998.

Yücer, H. Mahmut ve Sedat Küçük. "Tasavvuf Literatüründe Ağaç Sembolizmi ve Muhyî’nin Temsîl-i-Şecer İsimli Eseri”. Akademik Platform İslami Araştırmalar Dergisi 3/1 (2019): 13-28. 